\title{
Resolution of inflammation during multiple sclerosis
}

\author{
F. Ruiz ${ }^{1} \cdot$ S. Vigne ${ }^{1} \cdot$ C. $_{\text {Pot }^{1}}$ (I)
}

Received: 15 July 2019 / Accepted: 27 September 2019/Published online: 15 November 2019

(C) The Author(s) 2019

\begin{abstract}
Multiple sclerosis (MS) is a frequent autoimmune demyelinating disease of the central nervous system (CNS). There are three clinical forms described: relapsing-remitting multiple sclerosis (RRMS), the most common initial presentation (85\%) among which, if not treated, about half will transform, into the secondary progressive multiple sclerosis (SPMS) and the primary progressive MS (PPMS) $(15 \%)$ that is directly progressive without superimposed clinical relapses. Inflammation is present in all subsets of MS. The relapsing/ remitting form could represent itself a particular interest for the study of inflammation resolution even though it remains incomplete in MS. Successful resolution of acute inflammation is a highly regulated process and dependent on mechanisms engaged early in the inflammatory response that are scarcely studied in MS. Moreover, recent classes of disease-modifying treatment (DMTs) that are effective against RRMS act by re-establishing the inflammatory imbalance, taking advantage of the pre-existing endogenous suppressor. In this review, we will discuss the active role of regulatory immune cells in inflammation resolution as well as the role of tissue and non-hematopoietic cells as contributors to inflammation resolution. Finally, we will explore how DMTs, more specifically induction therapies, impact the resolution of inflammation during MS.
\end{abstract}

Keywords Multiple sclerosis - Suppressive immune cells · Innate immune cells · Neurovascular unit · Astrocytes · Blood-brain-barrier $\cdot$ Induction therapies

\section{Introduction}

Multiple sclerosis (MS) is a frequent autoimmune demyelinating disease of the central nervous system (CNS). The exact cause of MS remains elusive but it is certainly a multifactorial disease. Environmental factors, such as Epstein bar virus infection, low vitamin D status, or cigarette smoking contribute to MS development as well as genetic factors, in particular the HLA variant $H L A-D R B 1 * 15: 01$ [1]. The underlying physiopathology of MS is only partially unraveled. Most probably, auto reactive $\mathrm{CD}^{+} \mathrm{T}$ cells are activated in the periphery and cross the blood-brain barrier to reach the CNS, known as the

This article is a contribution to the special issue on Resolution of Inflammation in Chronic Diseases - Guest Editor: Markus Neurath

C. Pot

caroline.pot-kreis@chuv.ch

1 Laboratories of Neuroimmunology, Neuroscience Research Center and Service of Neurology, Department of Clinical Neurosciences, Lausanne University Hospital and University of Lausanne, Chemin des Boveresses 155, 1066 Epalinges, Switzerland "outside-in hypothesis." Once in the CNS, $\mathrm{CD}^{+}{ }^{+} \mathrm{T}$ cells are reactivated by local antigen presenting cells, which will trigger an inflammatory reaction, inducing the recruitment of other leukocytes (such as T cells, B cells, and macrophages). A second hypothesis, the "inside-out hypothesis," suggests that MS is a primary neurodegenerative disease that triggers an autoimmune reaction. We learned from murine models of MS, in particular the experimental autoimmune encephalomyelitis (EAE) and from the treatments that are effective to constrain MS, that the outside-in hypothesis is certainly valid. Peripheral leukocyte trafficking across the blood-brainbarrier is indeed an essential step in the initiation of relapses. The infiltration of pro-inflammatory leukocytes in the CNS further triggers a disruption of the myelin sheath eventually leading to neuronal loss [2]. However, what stimulates the peripheral infiltration of leukocytes into the CNS is still matter of debate.

Predominantly, the disease starts with a relapsing remitting course (RRMS), which may later convert into a secondary progressive disease (SPMS). In a minority of cases, the patients show progression from the onset without superimposed clinical relapses (primary progressive MS, PPMS) [3]. When the disease is progressive, the majority of disease-modifying treatments (DMTs) are inefficient probably because of the 
compartmentalization of the inflammation in the CNS. RRMS is characterized by flare-ups of neurological symptoms with periods of remissions. The relapses are characterized by an infiltration of peripheral immune cells across the blood-brain barrier (BBB), and blocking leukocyte trafficking from the periphery to the CNS is effective to treat RRMS.

In this review, we will focus on the factors implicated in the resolution of inflammation and discuss how they can be impaired in MS. We will first discuss the immune mechanism involved then the importance of non-immune compartment. Finally, we will briefly explore how diseasemodifying treatments impact inflammation resolution.

\section{Contribution of immune network to MS resolution}

Suppressive immune cells, both from the adaptive and innate immunity, prevent exaggerated inflammatory responses. We will first discuss the implication of $\mathrm{CD}^{+} \mathrm{T}$ cells, which can be subdivided based on their cytokine profiles in both pro- and anti-inflammatory subsets. Since the original classification by Mosmann and Coffman of $\mathrm{CD}^{+}$helper $\mathrm{T}$ (Th) lymphocytes into Th1 and Th2 subsets [4], their repertoire has expanded: for example, Th17 cells induce immunity against extracellular bacteria and fungi. Exaggerated Th17 response promotes autoimmunity and elevated levels of IL-17 are detected in MS. However, Th17 cells are heterogeneous and under certain conditions, IL-10 secretion renders them non-pathogenic [5]. However, we will here focus on $\mathrm{CD}_{4}^{+} \mathrm{T}$ regulatory $\mathrm{T}$ cell (Tregs) that are well-established players in the resolution of inflammation. Several classes of Tregs are identified: the FoxP3+ regulatory $\mathrm{T}$ cells that consist of conventional/ natural Treg (nTreg) cells and induced Tregs (iTregs) as well as the type 1 regulatory $\mathrm{T}(\operatorname{Tr} 1)$ cells [6]. We will then discuss the role of $\mathrm{CD} 8^{+} \mathrm{T}$ cells that outnumber $\mathrm{CD} 4^{+} \mathrm{T}$ cells in $\mathrm{MS}$ lesions and also contribute to inflammation resolution [7]. In addition, regulatory B cells (Breg) also restrain inflammation. Furthermore, innate immune cells in particular, subsets of NK cells, foamy macrophages as well as myeloid-derived suppressor cells contribute to inflammation resolution during MS [8]. Finally, the implication of pro-resolving lipid mediators (SPMs) in MS resolution will be explored. We will now discuss the implications of each of these immune cells and regulatory mechanisms in more detail.

\section{Role of FoxP3 ${ }^{+}$regulatory $\mathrm{T}$ cells (Tregs)}

$\mathrm{CD} 4^{+} \mathrm{CD} 25^{+} \mathrm{T}$ cells play a critical role in the regulation of CNS autoimmunity in EAE and MS (Fig. 1). Tregs influence EAE by affecting the priming, polarization, and proliferation of effector T cells in the periphery and within the CNS [9]. Transfer of Tregs in the periphery is sufficient to protect mice from the onset and the progression of both active and spontaneous EAE, whereas their depletion exacerbates the disease [10]. In the same line, the presence of myelin proteolipid protein-specific Tregs partially explains the genetic resistance to EAE disease observed in B10.S versus SJL mice. While both mouse models harbor $\mathrm{T}$ cells that recognize PLP139151 at similar frequencies upon immunization, EAEresistant B10.S mice fail to mount a sustained proliferative response due to a higher relative frequency of PLP-specific Tregs cells in their peripheral repertoire. Indeed, depletion of $\mathrm{CD} 25^{+}$cells in vivo restores EAE susceptibility to B10.S mice [11]. Furthermore, epigenetic modifications of the Foxp3 gene contribute to the pathogenesis of EAE [12]. Tregs are also implicated directly in the CNS at the site of inflammation resolution and can transmigrate across CNS endothelium [13]. In healthy CNS, Tregs are important in promoting neuroprotection as interactions occur between the resident cells of the CNS and the infiltrating Tregs to modulate the local immune responses [14]. During neuroinflammation, the frequencies of Tregs within the CNS are elevated during the recovery phase of actively induced EAE; however, it is not clearly established if they harbor suppressive activities, at least when tested ex-vivo [15]. At the experimental level, treatments that increase Tregs are beneficial; however, current techniques broadly expand polyclonal Tregs but not just Ag-specific cells. Promising studies indicate that tolerogenic nanoparticles induce antigen-specific Tregs and provide protection and transferable tolerance against EAE [16]. In the same way, gene therapy-induced antigen-specific Tregs prevent development and reverses pre-existing EAE [17]. Deficiency and/or dysfunction of Tregs are observed not only in EAE but also in MS [18]. However, whether Foxp3Tregs are deficient in the blood of MS patients has been a matter of debate for several years. To address this question, a meta-analysis regrouping 16 studies was published providing evidences that the proportion of Tregs expressing Foxp3 is indeed decreased in the peripheral blood of MS patients [19]. The assessment of Tregs directly in the CNS is however more challenging. Counter-intuitively, Foxp3+Tregs are increased in the CSF of MS patients; however, their functions are dampened in this compartment [20]. Those results are supported by genome-wide association studies (GWAS) that identified single nucleotide polymorphisms linked to Treg functions associated with an increased risk for MS disease [21].

\section{Role of IL-10-secreting type 1 regulatory T cells (Tr1)}

In contrast to conventional Tregs, $\operatorname{Tr} 1$ cells do not express the transcription factor Foxp3 and only a transient expression of CD25; however, they co-expressed CD49b, LAG-3, and CD226 cell-surface markers in humans and mice [22]. CMAF, AhR, BAFT, and IRF1 are critical transcription factors for $\operatorname{Tr} 1$ cell differentiation $[23,24]$. Tr1 cells exert their 


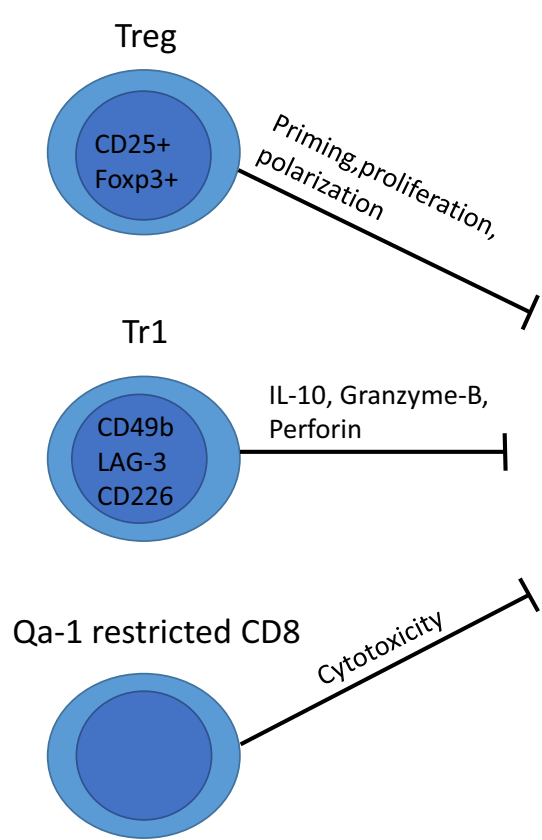

Fig. 1 Suppressive immune cells involved in inflammation resolution. Foxp $3^{+}$Treg cells affect priming, proliferation, and polarization of effector T cells both in the CNS and the periphery. Tr1 cells produce the anti-inflammatory cytokine IL-10 and kill effector cells via granzyme-B and perforin. Qa-1-restricted $\mathrm{CD}^{+}$cells have a cytotoxic effect on

immunosuppressive effects through IL-10 expression and by killing effector cells via Granzyme-B and Perforin (Fig. 1) [6]. Several studies have reported the critical involvement of IL-10 cytokine in the suppression of EAE models associated with an increase in $\operatorname{Tr} 1$ cells [25]. In EAE, the transfer of in vitro generated OVA-specific Tr1 cells prevents the development of neurological symptoms when OVA peptide is injected intracranially [26]. Moreover, in vivo induction of Tr1 cells with soluble myelin basic protein (MBP) reverses ongoing disease in rats immunized with MBP [27]. Regulatory Tr1 cells regulate EAE partially through a mechanism involving IL-10 [28]. Myelinspecific Tr1 cells injected mice-mediated delay onset of EAE associated with a reduction in the severity of clinical signs [29]. Another challenge is to successfully induce regulatory $\mathrm{T}$ cells directly in vivo to avoid $\mathrm{T}$ cell transfer that is challenging in humans. Interestingly, nasal anti-CD3 administration can induce Tr1-like $\mathrm{T}$ cells in vivo that are further able to constrain inflammation in the progressive animal model of multiple sclerosis in an IL-10-dependent manner by regulating astrocytes and microglia function [30]. Tr1 cells also display immunosuppressive functions in the human setting. Tr1 cells isolated from MS patients display impaired IL-10 production and altered IL10-mediated suppressive effects when compared with healthy controls $[31,32]$. In this line, considering that $\operatorname{Tr} 1$ function is impaired in MS, some studies investigated the effect of $\operatorname{Tr} 1$ differentiation by tolerogenic dendritic cells (tolDCs). A phase $1 \mathrm{~b}$ clinical trial showed the feasibility and safety of treating a patient with MS with tolDCs loaded with myelin peptides to increase IL-10 levels in PBMCs as well as the frequency of Tr1

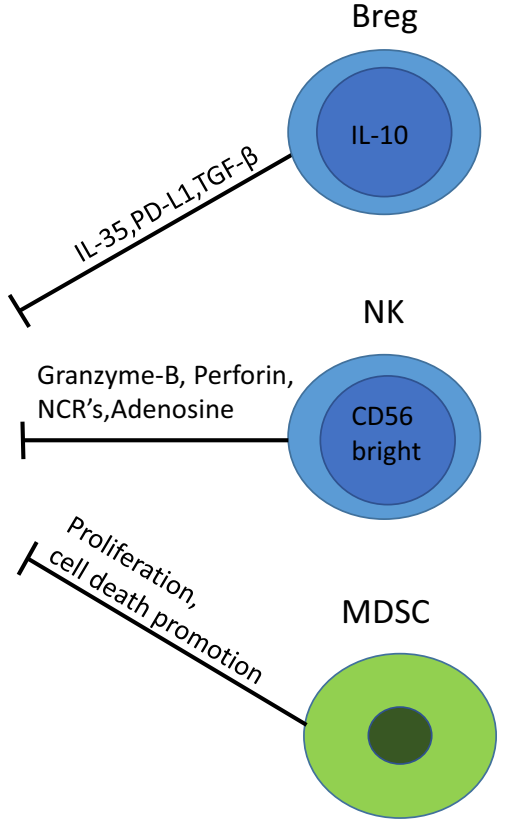

activated $\mathrm{CD}^{+}{ }^{+} \mathrm{T}$ cells. Bregs secrete IL- 35 and TGF- $\beta$ that suppress APC function. NK cell engagement of NCRs suppresses $\mathrm{CD}^{+}{ }^{+} \mathrm{T}$ cell proliferation and exerts a cytotoxic activity via the release of granzyme$\mathrm{B}$, perforin, and of the immunosuppressive adenosine. CNS-derived MDSCs suppress proliferation and promote cell death of lymphocytes

cells [33]. Furthermore, tolDCs exert some of their effects through the cytokine IL-27 that has been identified as a key inducer of Tr1 and inhibitor of Th17 during autoimmunity [6, 24]. IL-27 plays a suppressive role during EAE as demonstrated by more severe disease in IL-27R-deficient mice [34]. Furthermore, IL-27 treatment reduces the severity of EAE by a mechanism dependent on IL-10 [35]. Relevant to the human disease, the beneficial impact of IFN $\beta$, first-line therapy for relapsing-remitting MS, is associated with IL-27 induction, which promotes the production of IL10 by dendritic cells [36]. Finally, IL-27 is expressed by astrocytes in brain biopsies of human MS lesions suggesting that IL-27 regulates T cell response also locally within the brain of MS patients [37]. Therefore, IL-27 (acting on Tr1 cells) plays a critical role in controlling autoimmunity, providing a putative target therapy.

\section{Role of regulatory CD8 cells}

Similarly to $\mathrm{CD} 4^{+} \mathrm{T}$ cells, $\mathrm{CD} 8^{+} \mathrm{T}$ cells are both detrimental and protective during EAE and probably MS. After the identification of $\mathrm{CD} 8$ as being protective during EAE [38], the importance of the Qa-1 protein, an $\mathrm{MHC}$ class $1 \mathrm{~b}$ molecule (mouse equivalent of HLA-E for human), as a key molecule in CD8-meditated suppression was highlighted [39]. Qa-1/HLA-E-restricted $\mathrm{CD} 8^{+}$Tregs reduce EAE by promoting a cytotoxic activity on activated $\mathrm{CD}^{+} \mathrm{T}$ cells (Fig. 1) [40]. By performing screening for TCR specificity, peptides specific for the TCRs of clonally expanded $\mathrm{CD}^{+} \mathrm{T}$ cells were identified. Concomitant immunization with myelin and those peptides reduces EAE severity by 
expanding CD8 T cells that limited the proliferation of myelinspecific $\mathrm{CD}^{+} \mathrm{T}$ cells [41]. During an MS exacerbation, $\mathrm{CD} 8^{+}$ HLA-E-restricted show an impaired cytotoxic activity against activated myelin-specific $\mathrm{CD} 4^{+} \mathrm{T}$ cells [42]. Moreover, neuroantigen-specific $\mathrm{CD} 8^{+} \mathrm{T}$ cells are observed in both MS patients and healthy subjects [43] but their suppressive function is reduced during MS relapses [44]. A meta analysis evaluating the differences of frequency of $\mathrm{CD} 8^{+}$Tregs between healthy volunteer and MS patients lead to the conclusion that $\mathrm{CD} 8^{+}$ Tregs frequency is reduced in MS patients [45]. Furthermore during EAE, while most of the expanded $\mathrm{CD} 4^{+} \mathrm{T}$ cells are myelin specific, the majority of clonally expanded $\mathrm{CD} 8^{+} \mathrm{T}$ cells are not activated by myelin protein [41].

\section{Role of regulatory $B$ cells}

Regulatory B cells (Bregs) represent a small population of B cells, which participates in immunoregulation and suppression of immune responses. Due to the limited data on the phenotype of Bregs, they are usually identified by their capacity to secrete IL-10 and are termed B10 cells (Fig. 1). Apart from their IL-10 production, Bregs exert their functions by the expression of other regulatory cytokines such as TGF $\beta$ and IL-35 or by the generation and maintenance of Tregs. The role of $B$ cells itself remained elusive for many years, and initially, it was proposed using B cell-deficient mice, that B cells did not play a major role in the activation of encephalitogenic $\mathrm{T}$ cells but may solely partially contribute to the immune modulation in EAE [46]. The roles of $\mathrm{B}$ cells were further studied using B cell-targeted monoclonal antibodies (anti-CD20). While B cell depletion is beneficial if performed during disease activity, their depletion prior to EAE induction increases encephalitogenic $\mathrm{T}$ cell influx into the CNS in the $\mathrm{MOG}_{35-55}$ model of EAE [47]. By using the same strategy, Ray et al. found that B cell depletion prior the onset of EAE resulted in chronic disease induced by adoptive transfer of MBP-specific encephalitogenic T cells [48]. Further studies showed that transfer of B10 cells in mice suppresses active and spontaneous EAE in different mouse strains [49, 50]. The suppressive capacity of Breg during EAE is also dependent on coinhibitory molecules that downregulates effector $\mathrm{T}$ cell responses and elevated PD-L1 expression on B cells suppresses EAE [51]. In addition, IL-35 expression is also implicated in EAE recovery [52]. Finally, the presence of B cell-secreted TGF $\beta$ limits the induction phase of EAE, further demonstrating the regulatory role of B cell-derived IL-35 or TGF $\beta$ during autoimmunity [53].

In MS pathogenesis, the role of Bregs remains unclear due to several contradictory reports. The number of Bregs was reported to be reduced [54], unaltered [55], or increased [56] ending in disagreement between studies evaluating the role of Breg cells in MS. Interestingly, plasmablasts and plasma cells (that are not targeted by anti-CD20 treatment) highly express IL-10 within MS lesions [57] suggesting that these cells may ameliorate inflammation. IgA+ plasma cells can be generated in the gut and be mobilized to the CNS to further contribute to inflammation resolution in EAE and possibly in MS [58]. The controversies on Bregs are certainly the consequence of variations in patient cohorts (state/form of the disease, treatments) but also due to the non-established phenotype of Bregs and may depend upon the stage of differentiation of B cells.

\section{Role of NK cells}

In addition to regulatory lymphocytes, innate immune cells depict immune-regulatory properties. NK cells are innate lymphocytes that were initially affected with effector function properties, in particular, anti-tumoral and anti-viral [59]. However, they also display regulatory functions, more specifically the subset of human NK cells that express CD56 at high levels (CD56 $6^{\text {bright }} \mathrm{NK}$ cells). CD56 $6^{\text {bright }} \mathrm{NK}$ cells are a small fraction of circulating NK cells but constitute a large proportion of NK cells within lymph nodes and CSF. NK cells are detected in the CSF of both healthy and MS patients and can be considered as a CNS-specific marker, probably entering the CNS by the lymphatic vessels. NK cells can be activated by the pro-inflammatory cytokines IL-12 and IL-15 and thus are a good prototype of cells induced in the context of inflammation to promote its resolution. Interestingly, IL-27, which drives $\operatorname{Tr} 1$ cell generation, further enhances the antiinflammatory functions of CD56 $6^{\text {bright }} \mathrm{NK}$ cells [60]. In human, CD56 $6^{\text {bright }} \mathrm{NK}$ cells control T cell responses by several different mechanisms: contact-dependent suppression via perforin and granzyme B, via engagement of natural cytotoxicity receptors (NCRs) or via the secretion of the immunosuppressive molecule adenosine (Fig. 1) [61]. Interestingly, while the numbers of NK cells are similar in control and MS patients, NK cells from MS patients depict a lack of regulatory functions [62]. In EAE, the role of NK cells is more tedious to evaluate, as murine NK cells do not express the surface marker CD56. However, expression of other markers can further identify regulatory murine NK cells. For example, enhancing regulatory $\mathrm{NGK}^{+}{ }^{+} \mathrm{NK}$ cells dampens EAE disease by killing $T$ and microglia cells in the CNS in the acute phase of EAE. In MS, modulating CD56 $6^{\text {bright }} \mathrm{NK}$ cell functions was used as a strategy to tackle inflammatory processes. Indeed, daclizumab, a drug used to treat MS and that blocked the IL$2 \mathrm{R} \alpha$ chain (CD25), was associated with expansion and activation of $\mathrm{CD} 56^{\text {bright }} \mathrm{NK}$ cells that further controlled $\mathrm{T}$ cell activation [63]. While daclizumab was efficient against MS flare, it was withdrawn from the market after several cases of systemic autoimmunity complications occurred [64].

\section{Role of foamy macrophages}

Histological assessment of the resolving lesion in MS suggests that activated macrophages/microglia play a role in inflammation resolution [65]. Microglia and macrophages can 
be both detrimental and beneficial during EAE and MS [8]. Of particular interest, foamy macrophage/microglia, which phagocyte myelin, are present in the resolving lesion [65] and MS lesions in general. Foamy macrophages/microglia in MS lesions express anti-inflammatory mediators such as IL1ra, CCL18, IL-10, TGF-b, and IL-4 [66]. CD163 is considered as a marker of anti-inflammatory M2 macrophages [67], and it was shown that macrophages in acute MS lesions strongly express CD163 [68]. When challenged with LPS, macrophages that have ingested myelin showed reduced production of the pro-inflammatory cytokines TNF $\alpha$, IL-12p35, and IL-12/23p40 as compared to macrophages that have not ingested myelin [66]. Myelin uptake also increased the production of prostaglandin E2 and CCL18, two mediators that skew macrophages toward an M2 anti-inflammatory phenotype $[69,70]$. Myelin ingestion can activate both peroxisome proliferator-activated receptor $\beta / \delta(\operatorname{PPAR} \beta / \delta)$ [71] and liver $X$ receptor (LXR) [72]. Those two nuclear receptors are activated by lipids and can repress an inflammatory phenotype [73]. It should be noted that LXR is not a purely antiinflammatory receptor but can also promote inflammation in certain settings [74].

\section{Role of myeloid cells}

In all MS lesions type, the macrophages/microglia outnumber the lymphocytes [75]. Like all the cells constituting the immune cell network, innate immune cells are both detrimental and beneficial during MS. Among innate immune cells, a potentially interesting subpopulation is the myeloid-derived suppressor cells (MDSCs) that could play an important role in MS (Fig. 1). MDSCs were initially discovered in cancer [76]. They are constituted of heterogeneous populations of immature myeloid cells which have the common ability to suppress T cell proliferation [77]. Their implication in MS is only starting to be investigated and is complicated by the difficulty to define MDSCs (summarized elsewhere [78]). MDSCs accumulate in the CNS during EAE, are able to suppress $\mathrm{T}$ cell proliferation, and promote cell death in vitro [79]. In addition, the ability of some blood-derived myeloid cells to suppress $\mathrm{T}$ cell proliferation was impaired during EAE [80]. Furthermore, those suppressive cells accumulate within the lymphoid compartment during EAE [81] and adoptive transfer of MDSCs attenuates EAE [81]. To corroborate those findings, young mice are resistant to EAE and show a higher frequency of MDSCs [82]. In patients suffering from a MS relapse, the number of circulating MDSCs is increased. Interferon- $\beta$, a first-line treatment for MS, could act among many mechanisms by enhancing MDSC activity [83]. Studies are showing both increased and decreased frequencies of MDSCs in MS [81]. More recently, an inverted correlation between MDSCs and $\mathrm{CD} 138^{+} \mathrm{B}$ cells was observed in the CSF of MS patients [84] and CD138+ B cells are positively correlated with CNS inflammation [85]. Based on RNA sequencing analysis, MDSCs could acquire their suppressive phenotype directly in the CNS. They further prevent the accumulation of $\mathrm{B}$ cells in the CNS and contribute to dampening the inflammatory reaction [84]. A few publications implicating MDSCs in MS resolution and their potent immune suppressive activity indicates that it is a promising field toward a better understanding of MS resolution.

\section{Role of TNF and related cytokine}

Tumor necrosis factor (TNF) family genes are associated with MS. TNF- $\alpha$ is produced by several cell types including immune cells (macrophages or T cells) as well as CNSspecific cells (astrocytes or neurons) and can be detected in the CNS during MS [86]. It is active under two conformations: a transmembrane protein (tmTNF) and a soluble TNF (solTNF). TNF- $\alpha$ binds to two different receptors with different affinities: TNFR1, expressed on all cell types and TNFR2 mainly expressed on neurons, endothelial and immune cells [87]. SolTNF signals through TNFR1, mediating apoptosis, and chronic inflammation; tmTNF signals by binding both TNFR1 and TNFR2 and promotes resolution of inflammation [88]. TNF- $\alpha$ was initially proposed as a prototypical pro-inflammatory mediator and its expression is associated with MS disease progression [89]. However, blocking TNF- $\alpha$ pathway with lenercept, a recombinant soluble TNFR1 fusion protein strategy, failed as a treatment for MS and even lead to more exacerbations in patients treated with the drug compared to controls [90]. One possible explanation to this phenomenon is the inability of lenercept to enter the CNS [91]. However, treatments with soluble TNFR2 fusion protein (etanercept) or anti-TNF- $\alpha$ antibodies (infliximab) are also associated with the development of MS-like demyelinating lesions in patients treated for rheumatoid arthritis [92] suggesting that TNF- $\alpha$ is possibly actively involved in inflammation resolution and repair processes. First, TNF- $\alpha$ contributes to Treg expansion. Indeed, using in vitro coculture experiments with murine Foxp $3^{+}$Tregs and effector $\mathrm{T}$ cells (Teffs), short-term exposure to TNF- $\alpha$ promotes Teff expansion, and a longer exposition to TNF- $\alpha$ promotes Tregs activation [93]. TNRF2-deficient mice fail to expand Tregs under septic challenge and depict a worse EAE disease course [94]. Furthermore, TNFR2 signaling contributes to tissue repair specifically in the CNS and promotes the proliferation of immature oligodendrocytes [95]. Finally, selective blockade of solTNF improves EAE outcome by enhancing remyelination and axon preservation [95]. In addition, a polymorphism in TNF-related apoptosis-induced ligand (TRAIL) gene, a type II transmembrane protein that can induce apoptosis, is observed 
in MS [96]. As for TNF- $\alpha$, the TRAIL/TRAIL-receptor pathway has double roles during neuroinflammation. First, activating TRAIL pathway induces neurotoxicity causing inflammation and cell death [97]. On the other hand, it contributes to inflammation resolution in the CNS as chronic blockade of TRAIL pathway promotes inflammation and demyelination during EAE [98]. In conclusion, the roles of TNF and TNF-related genes on inflammation resolution remain a difficult but exciting area of research in MS.

\section{Lipid mediators during EAE and multiple sclerosis}

Specialized pro-resolving lipid mediators (SPMs) represent promising tools for the treatment of chronic inflammatory diseases. These highly potent anti-inflammatory lipids are derived metabolically from omega-3 essential fatty acids and include lipoxin a4 (LXA4) derived from arachidonic acid (AA), the D-series resolvins, protectins and maresins derived from docosahexaenoic acid (DHA), and the E-series resolvin derived from eicosapentaenoic acid (EPA). They are produced in the resolution phase of acute inflammation and have direct potent cellular responses to dampen inflammation and restore homeostasis [99]. SPMs affect both innate and adaptive immune cells by inhibiting DC maturation and function and/or modulating $\mathrm{T}$ and $\mathrm{B}$ cell phenotype and cytokine production [99]. Despite emerging data showing that SPMs might control neuroinflammation, research on these mediators in MS remains scarce. However, SPMs are produced in different tissues including the brain and cerebrospinal fluid [100] and accumulative evidence reveal that SPMs reduce neurodegenerative disease and protect neural cells in ischemic stroke or Alzheimer's disease [101, 102]. Furthermore, a connection between disease severity and lipid mediator production has been proposed as the resolving D1 and the neuroprotection D1 are increased in CSF of patients with highly active MS [103]. In contrast, bioinformatics analysis showed that the metabolites of PUFAs were downregulated in the plasma of EAE, which has also been reported in patients with MS [104]. In addition, oral administration of resolving D1 is effective in attenuating EAE disease progression by promoting Treg phenotype while attenuating the percentage of Th1/Th17 cells [104]. Similarly, the levels of resolving D1 decrease in the CSF of patients with neuromyelitis optica or MS compared to healthy patients, indicating dysfunction of resolution in MS patients [105]. Of note, researches in preclinical models and epidemiologic studies relating specific diets in the management of MS provide preliminary evidence that omega- 3 fatty acid supplementation beneficially influences both EAE and MS disease [106]. These observations further strengthen the therapeutic potential of SPMs derived from omega-3 essential fatty acids in the resolution neuroinflammation.

\section{Contribution of non-hematopoietic component: CNS network}

The CNS has been considered as an immune-privileged site for decades, based on an original finding that foreign tissue was not rejected when grafted in the CNS parenchyma [107]. The aim here is not to describe the mechanism at the origin of this immune-privilege but to discuss the putative role of nonhematopoietic cells in the resolution of inflammation. The intrinsically immuno-suppressive nature of the CNS is an important concept to consider when evoking local mechanisms that contribute to dampening an inflammatory reaction arising in the brain and spinal cord (Fig. 2a). The infiltration of peripheral leukocytes into the CNS is a key step at the origin of inflammatory cascade leading to MS relapses (Fig. 2b). Inbetween the blood circulation and the CNS parenchyma lies a "two-wall castle" [108] that needs to be crossed by leukocytes to trigger a relapse, the outer wall being either the highly specialized epithelial cells or endothelial cells respectively of the choroid plexus, i.e., the blood-cerebrospinal fluid barrier (BCSFB) and the CNS capillaries, i.e., blood-brain-barrier (BBB). The inner wall is called the glia limitans as is composed of astrocytic end-feet and the parenchymal basement membrane. In between those "two walls" is found the cerebrospinal fluid (CSF). Virtually, all the cellular networks constituting the CNS mediate pro-resolving mechanisms. The BBB constitutes a tightly regulated obstacle to leukocyte entry in the CNS and in itself can limit the infiltration by counterregulatory mechanisms. The BCSFB and the CSF serve as selective gateways that shift the infiltrating leukocytes toward a pro-resolving phenotype. The astrocytes, by the production of anti-inflammatory signals and by forming a physical barrier, are key in the MS relapse resolutions (Fig. 2b). Finally, neurons besides their numerous functions are also able to modulate the phenotype of immune cells. The highly specialized tightly sealed endothelial cells of the BBB are an obstacle for inflammatory immune cell trafficking into CNS [109]. However, the BBB endothelium should not be considered as just a simple physical barrier. The regulation of its permeability results from a dynamic cellular cross-talk between endothelial cells, astrocytes, pericytes, microglial cells, and neurons. Together, these cells form the neurovascular unit (NVU) [110].

\section{Astrocytes}

The impact of astrocytes in inflammation can be both detrimental and beneficial [111]. However, as the purpose of this review is to give an overview of the potential mechanism resolving an MS relapse, we will focus on protective mechanisms. Astrocytes produce anti-inflammatory cytokines in reaction to an inflammatory stimulus. Activation of human astrocytes by inflammatory cytokines induces the production of 
a

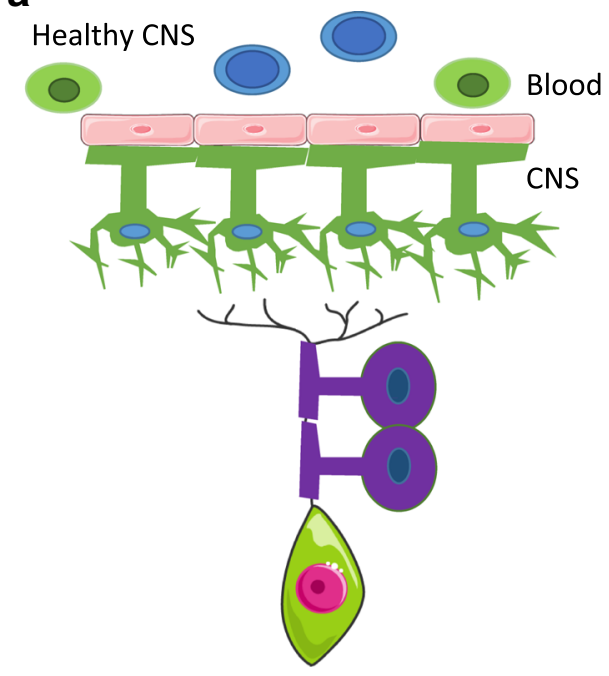

b MS relapse

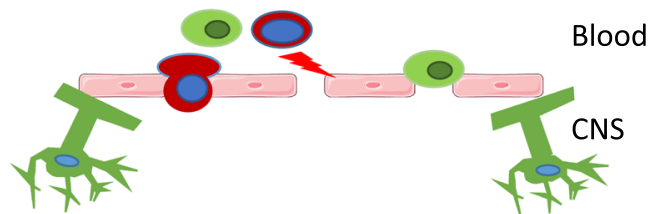

Myelin sheet disruption

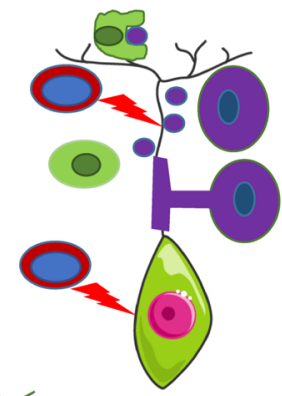

Astrocytes activation

Neuron activation

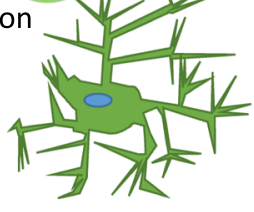

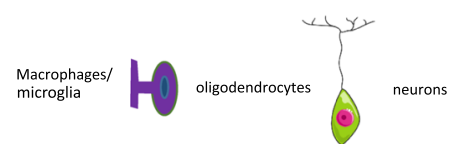

Fig. 2 Schematic representation of the CNS at steady-state and during a relapse. a. Healthy CNS. The endothelial cells of the BBB are ensheeted by astrocytic end-feet. The BBB is impermeable notably to leukocytes. Oligodendrocytes form the myelin layer that surrounds the axon. b CNS during MS. The blood-brain barrier is disrupted and the endothelial permeability is increased. The astrocytic end-feet are detached, allowing leukocytes to transmigrate and trigger an inflammatory cascade. Inflammatory signals produced by leukocytes activate astrocytes. The myelin sheet is disrupted and phagocytes start to remove myelin debris. Neurons are further activated during the inflammatory reaction
IL-27 [112], which is further able to reduce EAE symptoms [34]. In accordance with those results, RRMS patients have increased levels of IL-27 in the CSF [37] and astrocytes show an increased immune-reactivity of the IL-27 subunit EBI3 in MS lesions (Fig. 3) [37]. Furthermore, IL-6-deficient mice are resistant to EAE [113] and IL-6 activation of Gp130 in astrocytes is beneficial during EAE [114]. Using a CRE/Lox system, it has been observed that the specific depletion of gp130 in astrocytes leads to an increased EAE severity associated with a reduced number of FoxP3 ${ }^{+} \mathrm{CD}^{+}$Tregs cells, increased number of IL-17 and IFN- $\gamma$ producing $\mathrm{CD} 4{ }^{+} \mathrm{T}$ cells. The antiinflammatory cytokines IL-10 and IL-4 are upregulated in activated astrocytes in MS lesions [115]. Moreover, activation of human-induced pluripotent stem cell-derived astrocytes [116] by a combination of IL- $1 \beta$ and TNF- $\alpha$ induces IL-10 secretion. Finally, the implication of a proliferation of active ligand (APRIL) was explored in MS and EAE: EAE disease is worsened in mice deficient for APRIL. APRIL is expressed in MS lesions, and stimulation of astrocytes with this molecule induces IL-10 secretion that is sufficient to reduce T cell proliferation [117].

We will now explore how the astrocytes-endothelial cellular cross-talk can regulate leukocyte trafficking in MS and
EAE. The leukocyte infiltration into the CNS during a relapse is associated with BBB disruption, and thus, restoring or maintaining the endothelial permeability could be a potential mechanism to prevent an excessive infiltration during a relapse. Astrocytes and endothelial cells cross-talk regulate and limit leukocyte infiltration. A key pathway in this cellular cross-talk is the Hedgehog pathway (Hh) [118]. Sonic-hedgehog (Shh) production by astrocytes leads to a decreased endothelial permeability. Blocking the Hh pathways during EAE leads to more severe disease and increases the number of INF- $\gamma$ and IL-17 producing T cells in the CNS. Finally, increasing amounts of $\mathrm{Hh}$ elements are found in MS active lesions. Netrin 1 is produced by the endothelium in response to astrocytederived Shh and is upregulated in MS and EAE lesions. Treatment with Netrin 1 can reduce BBB disruption and disease severity during EAE (Fig. 3) [119].

Furthermore, astrocytes limit leukocyte infiltration in the CNS by forming a physical barrier. Any kind of injury in the CNS will lead to the activation of astrocytes, which will be translated into morphological and functional changes called reactive astrogliosis [120]. Reactive astrogliosis can be both beneficial and detrimental. Thus, activated astrocytes 
BBB permeability restoration

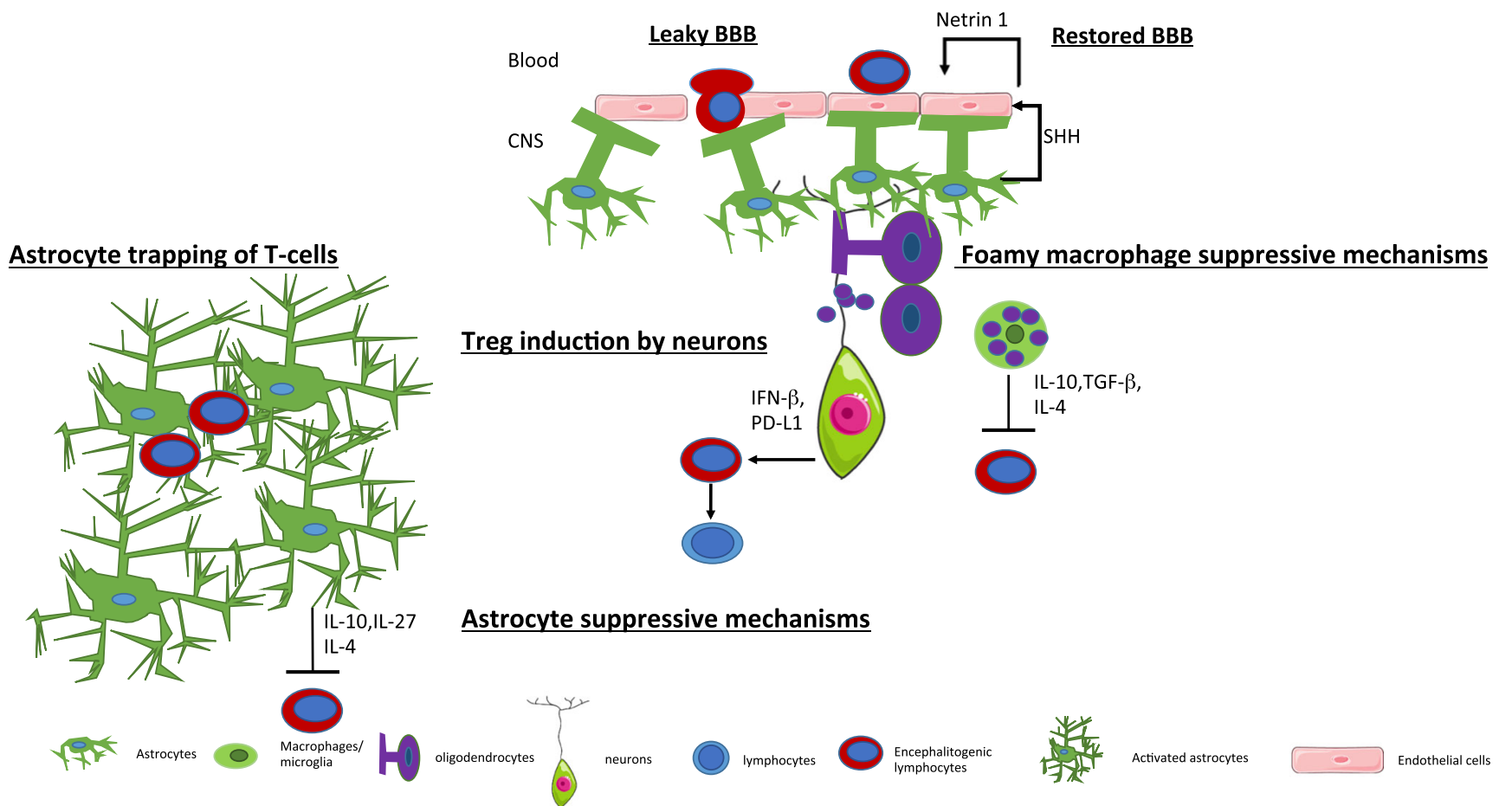

Fig. 3 CNS network mechanism promoting resolution. BBB permeability restoration: Shh derived from astrocytes promotes Netrin 1 production by endothelial cells. This pathway reduces the BBB permeability and limits leukocyte infiltration. Astrocytes trap T-cells: activated astrocytes form a physical barrier that limits leucocyte infiltration. Astrocyte suppressive mechanisms: activated astrocytes

attenuate the inflammatory reactions triggered by infiltrating leukocytes by forming a "scar-like perivascular barrier," a physical barrier that prevents the spread of infiltrating cells to the adjacent CNS [121]. More recently, it has been shown that astrocytes upregulate the tight junction protein CLDN1, CLDN4, and JAM-A when activated [122]. Furthermore, activated astrocytes are able to form interconnected processes leading to a "trap" able to enclose lymphocytes (Fig. 3). This phenomenon is dependent on the expression of CLD1, CLDN4, and JAM-A. Conditional mouse model deficient for CLDN4 in astrocytes leads to increased lesion sizes an increased number of infiltrating CD4 T cells per $\mathrm{mm}^{2}$ of lesions during EAE [122].

\section{Neurons actively participate in inflammation resolution during $\mathrm{MS}$.}

The contribution of neurons to the immune privileged site of the CNS is not well established; however, neurons harbor immunoregulatory functions. The interaction between neurons and encephalitogenic $\mathrm{T}$ cells induces the conversion of T cells into Foxp $3^{+}$Tregs (Fig. 3) [123]. A new type of regulatory cells enriched in the CNS of a relapsing-remitting model of EAE was described [124]. produce anti-inflammatory cytokines that repress encephalitogenic $\mathrm{T}$ cells. Treg induction by neurons: neurons can repolarize encephalitogenic $\mathrm{T}$ cell into FoxA1 ${ }^{+}$Tregs. Foamy macrophage-suppressive mechanisms: foamy macrophages produce anti-inflammatory cytokine that contribute to inflammation resolution

The generation of these Tregs cells is dependent on the expression of IFN- $\beta$, and their suppressive functions are mediated by the co-inhibitory molecule program death ligand-1 (PDL-1) as well as the expression of the lineage-specification factor FoxA1 (or hepatocytes nuclear factor 3alpha or HNF3 alpha). PDL-1 being mentioned here, we take this opportunity to stress the role of checkpoint inhibitors. Given the increasing number of checkpoint inhibitors such as those that target the PD-1/PDL-1 pathway, notably in the field of oncology, the importance of those inhibitory signals in autoimmunity has been increasingly recognized. Altering checkpoint inhibitory pathways can trigger or worsen CNS autoimmune diseases. For an overview of the implication of those immune-checkpoint and their inhibitors in CNS autoimmune diseases, we refer the reader to the following review [125]. Using a CRE/Lox system, it has been proposed that IFN- $\beta$ production by neurons is essential to generate FoxA1 Treg cells [126]. Selective depletion of IFN- $\beta$ expression in neurons leads to an increased number of infiltrating cells in the spinal cord during EAE. The potential implication of neurons as active immune-modulators in MS is an interesting concept that could benefit from deeper investigations. 


\section{Choroid plexus}

The epithelial cells of the choroid plexus form the BCSFB. Like the BBB, epithelial cells of the choroid plexus are sealed together with tight junctions [127]. The barrier is thus not formed by the endothelial cells of the choroid plexus which are fenestrated [128]. So far, there is no documentation that crossing the blood-brain barrier could skew leukocytes toward an anti-inflammatory phenotype but the choroid plexus could be considered as a selective gate, facilitating the passage of regulatory cells to the CNS [129]. Moreover, once they have crossed the BCSFB, immune cells reach to cerebrospinal fluid that itself is a suppressive environment [130]. In a model of spinal cord injury, pro-resolving M2 macrophages are reaching the CNS by crossing the BCSFB rather than crossing the BBB at the site of the lesion [131]. The CSF and the choroid plexus are an M2-skewing environment, illustrated by the presence of high levels of IL-13 and TGF- $\beta$ [131]. However, the implication of the BCSFB as a selective proresolving gateway in the context of MS has not been investigated. So far, the evidence suggests that in this context, the choroid plexus rather serve as a primary route of entry for autoreactive lymphocytes [132]. The CCL20 chemokine ligand of CCR6 is constitutively expressed at the choroid plexus [132]. CCR6 is expressed by Th17 cells; it is suggested that during EAE, there are primary wave Th17 cells that reach the CNS by crossing the BCSFB. This primary inflammatory infiltrate would then trigger and the second wave of leukocyte infiltration that would reach the CNS via the BBB in a CCR6independent manner [132]. It is not excluded that while choroid plexus could serve as an initial route of entry for autoreactive cells in EAE and MS; its pro-resolving nature illustrated in another context could be beneficial during the recovery phase. As Foxp3+Treg also expresses CCR6 [133] during EAE, the choroid plexus could also serve as a site for the recruitment of those cells.

\section{Endothelial cells in the BBB}

Since leukocyte infiltration in the CNS is a tightly regulated process, multiple mechanisms are involved. One treatment strategy to target MS is to inhibit lymphocyte adhesion to the endothelium. Developmental locus-1 (DEL-1) is highly expressed in the CNS [134]. The absence of DEL-1 in the endothelium leads to an increased leukocyte function antigen 1 (LFA-1)-dependent adhesion to the endothelium. Interestingly, mutation in the gene encoding DEL-1 (EDIL3) is associated with MS [135]. DEL-1-deficient-mice display a more severe EAE than their wild-type counterpart [136]. This phenotype is associated with an increased BBB permeability and infiltration of neutrophils together with increased level of IL-17 possibly produced by CD8 T cells. DEL-1 expression is downregulated in chronic active lesions in MS and in EAE
[136]. Rather than being a simple adhesion inhibitor, DEL-1 seems to have a pro-resolution function by promoting efferocytosis, a process by which macrophages phagocyte apoptotic neutrophils and acquire a pro-resolution phenotype [137] notably by LXR activation. The implication of this pathway remains to be explored during MS.

\section{Impact of disease treatment on inflammation resolution}

Multiple treatment strategies are available to dampen inflammation in MS. We will here discuss the potential impact of MS treatments on inflammation resolution, first with the treatment of relapse with high-dose of corticosteroids and then novel disease-modifying treatments (DMTs). We will focus on inductive therapies that induce a reset of the immune system and promote component of inflammation resolution.

\section{Treatment of MS relapse: glucocorticoids}

MS course is influenced by the level of endogenous glucocorticoids (Gcs) that are mainly secreted from the adrenal gland in response to an activation of the hypothalamo-pituitary-adrenal (HPA) axis [138]. By interconverting active Gcs (cortisone, 11dehydrocorticosterone), 11 $\beta$-HSD modulates intracellular access of glucocorticoid to receptors. Type $111 \beta-H S D(11 \beta-$ HSD1) reactivates glucocorticoids and increases intracellular glucocorticoid concentration while type $211 \beta$-HSD $(11 \beta-$ HSD2) inactivates Ges in vivo. MS patients show lower cortisol levels in the CSF during acute relapses that may be secondary to poor local activation of cortisone via $11 \beta-H S D 1$ or to inactivation via $11 \beta-H S D 2$. In the CNS, differential expression of $11 \beta$ HSD1 and 2 expressions in foamy macrophages possibly contribute to the resolution of acute inflammation in MS. The second important "neurosteroids" is the dehydroepiandrosterone (DHEA). In addition to cortisone (the natural metabolite), synthetic steroids are also substrates for the $11 \beta$-HSD enzymes. Synthetic Gcs have higher affinity, greater bioavailability, and are poorly metabolized, and thus persist in plasma much longer than endogenous glucocorticoids (cortisol). High-dose corticosteroid medication is thus used to shorten the duration of a relapse and to accelerate its recovery. Corticosteroids have robust anti-inflammatory properties [139], such as induction of T cell apoptosis and inhibition of BBB disruption. They further play an active role in the resolution of inflammation as they increase regulatory $\mathrm{T}$ (Treg) number and enhance their suppressive capacities [140]. Indeed, steroid treatment in mice increases the relative number of $\mathrm{CD} 4^{+} \mathrm{CD} 25^{+}$Treg cells, which are more resistant to GC-induced apoptosis due to a higher expression of $\mathrm{Bcl}-2$ and increased levels of CTLA-4. In humans, the percentage of Treg cells in MS patients is increased after short-term GC therapy [141]. Effects on Treg cells presumably contribute to the 
therapeutic efficacy of Gcs by favoring active resolution of inflammation during an MS relapse. However, glucocorticoids have no impact on the long-term MS disease course and are not considered as disease-modifying treatment (DMTs).

\section{Disease-modifying treatments}

Disease-modifying treatments (DMTs) are divided in two main approaches: the first DMTs are efficacious through a mechanism of continuous immunosuppression; the second are induction therapies where DMTs reshape the immune system toward a new immune system less prone to disease activity. We will here focus on the second approach, not because it is more commonly used but because of its possible contribution to long-term inflammation resolution. The prototype of induction therapy is the autologous hematopoietic stem cell transplantation (aHSCT) that consists of first mobilization of $\mathrm{CD} 34^{+}$ hematopoietic stem cells, then an immunoablative conditioning followed by HSC transplantation. aHSCT enables recalibration of the immune system and restores the predominance of anti-inflammatory regulating factors over inflammatory effectors. These mechanisms may explain induction of long-lasting suppression of some autoimmune diseases by aHSCT with the development of a tolerant environment. Tregs are both quantitatively and qualitatively modified in MS patients after aHSCT (review in [142]). The effect of aHSCT on Bregs has not been evaluated in MS but Bregs are increased when aHSCT is performed in patients suffering from systemic sclerosis [143]. Increased PD-1 inhibitory signaling is another possible immunoregulatory mechanism by which aHSCT restores immune tolerance in MS patients with early expansion of PD- $1^{+} \mathrm{CD} 8^{+} \mathrm{T}$ cells and of PD-1expressing $\mathrm{CD}_{1} 9^{+} \mathrm{B}$ cells. PD-1/PDL pathways play a role in MS and in mouse model of EAE, blockade of PDL1 or PDL2 accelerates disease course and severity [144]. An association between PD-1 deficiency and MS progression is reported: PD-1 expression is higher on MBP-specific $\mathrm{CD}^{+}$and $\mathrm{CD} 8^{+} \mathrm{T}$ cells during remission compared to acute relapses [145].

In addition, alemtuzumab leads to a "reset of the immune system." This treatment administered as a pulsed therapy targets $\mathrm{CD}_{2}{ }^{+}$cells and depletes T, B, and NK cells followed by an immune reconstitution. Alemtuzumab increased the antiinflammatory IL- 10 and TGF- $\beta$ cytokine levels within 6 months of treatment and further increase Treg percentage and function after 24 months post-treatment [146]. However, alemtuzumab increases the percentage of repopulated naive/immature B cells and possibly the hyper-population of naïve $\mathrm{B}$ cell population regenerating before Tregs induce systemic loss of immunetolerance and secondary autoimmunity that can be severe and limits its use in the clinic [147]. Finally, cladribine can be considered as an inductive therapy. It is a purine analog, a prodrug whose metabolite selectively accumulates in lymphocytes inducing specific lymphocyte depletion. Cladribine therapy may have a profile of immune-reconstitution closer to aHSCT compared to alemtuzumab [147].

\section{Open questions and concluding remarks}

It is legitimate to argue that an inflammatory misbalance is at the origin of MS. Research on pro-inflammatory mechanisms in MS has been largely studied; however, the potential mechanisms that actively participate in resolving inflammation were scarcely evaluated. In fact, autoimmune diseases in general could come as much from an excess of inflammation as from a deficit of proresolutive mechanism or as a combination of both. For example, even if it is purely speculative, the DEL-1 mutation associated with MS [135] could result in a loss of function leading to enhanced leukocyte adhesion and transmigration across the BBB while at the same time, it could contribute to disrupting efferocytosis, an important process for inflammation resolution [148]. In MS, the lack of full resolution of inflammation probably participates to persistent chronic inflammation. For this reason, the comparison of immune responses between MS and other self-limited inflammatory diseases of the CNS like ADEM or viral encephalitis could help in understanding the specific mechanisms that lead to chronic inflammation. A first response to this question was addressed in pediatric neuroinflammatory diseases [149]. By comparing both abnormal effector and regulatory $\mathrm{T}$ cells, subsets in children with either MS or monophasic inflammatory CNS disorders, the authors could identify specific abnormalities in MS but not in other self-limited diseases. Only children with MS presented with both an exaggerated pro-inflammatory response of $\mathrm{CD}^{+}$Teff cells that were resistant to suppression to Tregs as well as deficient suppressive capacities of Tregs (more specifically $\mathrm{CD} 4^{+} \mathrm{CD} 25^{\text {hi }} \mathrm{CD} 127^{\text {low }} \mathrm{Foxp}^{+}$Tregs) [149].

Furthermore, the resolution of inflammation is the results of a complex collaboration between the network of peripheral and resident immune cells together with the local cells of the CNS. Along the same lines, it is important to develop new models that specifically mimic inflammatory processes that take place in MS. Interestingly, an alternative rat EAE model that induces focal cortical demyelinating lesions could highlight that rapid resolution of inflammation contributes to more efficient remyelination [150]. A better understanding of this endogenous pro-resolutive mechanism could lead to novel therapeutic approaches. Notably, the use of SPMs for relapse treatment could be a promising new therapeutic approach also in MS. Similarly, favoring astrocytic reaction that prevents the 
spread of the lesion could reduce the potential disability induced by a relapse. Favoring and accelerating inflammation resolution could be beneficial in terms of preventing the accumulation of disability that we see in RRMS patients.

In conclusion, the understanding of the immunopathogenic mechanisms involved in resolution of inflammation in MS remains an important research field. Thus, a better understanding of resolution of inflammation in MS could result in interesting alternative approaches toward improvement in the treatments of MS patients.

Acknowledgements The authors thank P. Dubois-Ferriere for proofreading the manuscript.

Funding information This work was supported by the Swiss National Science Foundation (no. PP00P3_157476 to CP) and the Leenaards foundation. FR holds a MD-PhD grant from the Swiss National Science Foundation (no. 323630-183987 to FR).

\section{Compliance with ethical standards}

Conflict of interest The authors declare that they have no conflict of interest.

Open Access This article is distributed under the terms of the Creative Commons Attribution 4.0 International License (http:// creativecommons.org/licenses/by/4.0/), which permits unrestricted use, distribution, and reproduction in any medium, provided you give appropriate credit to the original author(s) and the source, provide a link to the Creative Commons license, and indicate if changes were made.

\section{References}

1. Dendrou CA, Fugger L, Friese MA (2015) Immunopathology of multiple sclerosis. Nat Rev Immunol 15:545-558

2. Trapp BD, Nave KA (2008) Multiple sclerosis: an immune or neurodegenerative disorder? Annu Rev Neurosci 31:247-269

3. Lublin FD, Reingold SC, Cohen JA, Cutter GR, Sorensen PS, Thompson AJ, Wolinsky JS, Balcer LJ, Banwell B, Barkhof F, Bebo B Jr, Calabresi PA, Clanet M, Comi G, Fox RJ, Freedman MS, Goodman AD, Inglese M, Kappos L, Kieseier BC, Lincoln JA, Lubetzki C, Miller AE, Montalban X, O'Connor PW, Petkau J, Pozzilli C, Rudick RA, Sormani MP, Stuve O, Waubant E, Polman CH (2014) Defining the clinical course of multiple sclerosis: the 2013 revisions. Neurology 83:278-286

4. Mosmann TR, Cherwinski H, Bond MW, Giedlin MA, Coffman RL (1986) Two types of murine helper T cell clone. I. Definition according to profiles of lymphokine activities and secreted proteins. J Immunol 136:2348-2357

5. Wu X, Tian J, Wang S (2018) Insight into non-pathogenic Th17 cells in autoimmune diseases. Front Immunol 9:1112

6. Pot C, Apetoh L, Kuchroo VK (2011) Type 1 regulatory T cells (Tr1) in autoimmunity. Semin Immunol 23:202-208

7. Salou M, Garcia A, Michel L, Gainche-Salmon A, Loussouarn D, Nicol B, Guillot F, Hulin P, Nedellec S, Baron D, Ramstein G, Soulillou JP, Brouard S, Nicot AB, Degauque N, Laplaud DA (2015) Expanded CD8 T-cell sharing between periphery and CNS in multiple sclerosis. Ann Clin Transl Neurol 2:609-622
8. Grajchen E, Hendriks JJA, Bogie JFJ (2018) The physiology of foamy phagocytes in multiple sclerosis. Acta Neuropathol Commun 6:124

9. Koutrolos M, Berer K, Kawakami N, Wekerle H, Krishnamoorthy G (2014) Treg cells mediate recovery from EAE by controlling effector T cell proliferation and motility in the CNS. Acta Neuropathol Commun 2:163

10. Montero E, Nussbaum G, Kaye JF, Perez R, Lage A, Ben-Nun A, Cohen IR (2004) Regulation of experimental autoimmune encephalomyelitis by CD4+, CD25+ and CD8+ T cells: analysis using depleting antibodies. J Autoimmun 23:1-7

11. Reddy J, Illes Z, Zhang X, Encinas J, Pyrdol J, Nicholson L, Sobel RA, Wucherpfennig KW, Kuchroo VK (2004) Myelin proteolipid protein-specific CD4+CD25+ regulatory cells mediate genetic resistance to experimental autoimmune encephalomyelitis. Proc Natl Acad Sci U S A 101:15434-15439

12. Noori-Zadeh A, Mesbah-Namin SA, Saboor-Yaraghi AA (2017) Epigenetic and gene expression alterations of FOXP3 in the Tcells of EAE mouse model of multiple sclerosis. J Neurol Sci 375:203208

13. Schneider-Hohendorf T, Stenner MP, Weidenfeller C, Zozulya AL, Simon OJ, Schwab N, Wiendl H (2010) Regulatory T cells exhibit enhanced migratory characteristics, a feature impaired in patients with multiple sclerosis. Eur J Immunol 40:3581-3590

14. Beers DR, Henkel JS, Zhao W, Wang J, Huang A, Wen S, Liao B, Appel SH (2011) Endogenous regulatory T lymphocytes ameliorate amyotrophic lateral sclerosis in mice and correlate with disease progression in patients with amyotrophic lateral sclerosis. Brain 134:1293-1314

15. Korn T, Reddy J, Gao W, Bettelli E, Awasthi A, Petersen TR, Backstrom BT, Sobel RA, Wucherpfennig KW, Strom TB, Oukka M, Kuchroo VK (2007) Myelin-specific regulatory T cells accumulate in the CNS but fail to control autoimmune inflammation. Nat Med 13:423-431

16. LaMothe RA, Kolte PN, Vo T, Ferrari JD, Gelsinger TC, Wong J, Chan VT, Ahmed S, Srinivasan A, Deitemeyer P, Maldonado RA, Kishimoto TK (2018) Tolerogenic nanoparticles induce antigenspecific regulatory $\mathrm{T}$ cells and provide therapeutic efficacy and transferrable tolerance against experimental autoimmune encephalomyelitis. Front Immunol 9:281

17. Keeler GD, Kumar S, Palaschak B, Silverberg EL, Markusic DM, Jones NT, Hoffman BE (2018) Gene therapy-induced antigenspecific Tregs inhibit neuro-inflammation and reverse disease in a mouse model of multiple sclerosis. Mol Ther 26:173-183

18. Danikowski KM, Jayaraman S, Prabhakar BS (2017) Regulatory $\mathrm{T}$ cells in multiple sclerosis and myasthenia gravis. J Neuroinflammation 14:117

19. Li YF, Zhang SX, Ma XW, Xue YL, Gao C, Li XY, Xu AD (2019) The proportion of peripheral regulatory $\mathrm{T}$ cells in patients with multiple sclerosis: a meta-analysis. Mult Scler Relat Disord 28: 75-80

20. Feger U, Luther C, Poeschel S, Melms A, Tolosa E, Wiendl H (2007) Increased frequency of CD4+ CD25+ regulatory T cells in the cerebrospinal fluid but not in the blood of multiple sclerosis patients. Clin Exp Immunol 147:412-418

21. Lowther DE, Hafler DA (2012) Regulatory T cells in the central nervous system. Immunol Rev 248:156-169

22. Gagliani N, Magnani CF, Huber S, Gianolini ME, Pala M, LiconaLimon P, Guo B, Herbert DR, Bulfone A, Trentini F, Di Serio C, Bacchetta R, Andreani M, Brockmann L, Gregori S, Flavell RA, Roncarolo MG (2013) Coexpression of CD49b and LAG-3 identifies human and mouse T regulatory type 1 cells. Nat Med 19:739-746

23. Apetoh L, Quintana FJ, Pot C, Joller N, Xiao S, Kumar D, Burns EJ, Sherr DH, Weiner HL, Kuchroo VK (2010) The aryl hydrocarbon receptor interacts with c-Maf to promote the differentiation 
of type 1 regulatory T cells induced by IL-27. Nat Immunol 11: 854-861

24. Pot C, Jin H, Awasthi A, Liu SM, Lai CY, Madan R, Sharpe AH, Karp CL, Miaw SC, Ho IC, Kuchroo VK (2009) Cutting edge: IL27 induces the transcription factor c-Maf, cytokine IL-21, and the costimulatory receptor ICOS that coordinately act together to promote differentiation of IL-10-producing Tr1 cells. J Immunol 183: 797-801

25. Beebe AM, Cua DJ, de Waal Malefyt R (2002) The role of interleukin-10 in autoimmune disease: systemic lupus erythematosus (SLE) and multiple sclerosis (MS). Cytokine Growth Factor Rev 13:403-412

26. Barrat FJ, Cua DJ, Boonstra A, Richards DF, Crain C, Savelkoul HF, de Waal-Malefyt R, Coffman RL, Hawrylowicz CM, O'Garra A (2002) In vitro generation of interleukin 10-producing regulatory CD4(+) T cells is induced by immunosuppressive drugs and inhibited by Thelper type 1 (Th1)- and Th2-inducing cytokines. J Exp Med 195:603-616

27. Wildbaum G, Netzer N, Karin N (2002) Tr1 cell-dependent active tolerance blunts the pathogenic effects of determinant spreading. $\mathrm{J}$ Clin Invest 110:701-710

28. Zhang X, Koldzic DN, Izikson L, Reddy J, Nazareno RF, Sakaguchi S, Kuchroo VK, Weiner HL (2004) IL-10 is involved in the suppression of experimental autoimmune encephalomyelitis by CD25+CD4+ regulatory T cells. Int Immunol 16:249-256

29. Raverdeau M, Christofi M, Malara A, Wilk MM, Misiak A, Kuffova L, Yu T, McGinley AM, Quinn SM, Massilamany C, Reddy J, Forrester JV, Mills KH. 2019. Retinoic acid-induced autoantigen-specific type 1 regulatory T cells suppress autoimmunity. EMBO Rep 20

30. Mayo L, Cunha AP, Madi A, Beynon V, Yang Z, Alvarez JI, Prat A, Sobel RA, Kobzik L, Lassmann H, Quintana FJ, Weiner HL (2016) IL-10-dependent Tr1 cells attenuate astrocyte activation and ameliorate chronic central nervous system inflammation. Brain 139:1939-1957

31. Astier AL, Meiffren G, Freeman S, Hafler DA (2006) Alterations in CD46-mediated $\operatorname{Tr} 1$ regulatory T cells in patients with multiple sclerosis. J Clin Invest 116:3252-3257

32. Martinez-Forero I, Garcia-Munoz R, Martinez-Pasamar S, Inoges S, Lopez-Diaz de Cerio A, Palacios R, Sepulcre J, Moreno B, Gonzalez Z, Fernandez-Diez B, Melero I, Bendandi M, Villoslada P (2008) IL-10 suppressor activity and ex vivo Tr1 cell function are impaired in multiple sclerosis. Eur J Immunol 38: 576-586

33. Zubizarreta I, Florez-Grau G, Vila G, Cabezon R, Espana C, Andorra M, Saiz A, Llufriu S, Sepulveda M, Sola-Valls N, Martinez-Lapiscina EH, Pulido-Valdeolivas I, Casanova B, Martinez Gines M, Tellez N, Oreja-Guevara C, Espanol M, Trias E, Cid J, Juan M, Lozano M, Blanco Y, Steinman L, BenitezRibas D, Villoslada P (2019) Immune tolerance in multiple sclerosis and neuromyelitis optica with peptide-loaded tolerogenic dendritic cells in a phase $1 \mathrm{~b}$ trial. Proc Natl Acad Sci U S A 116:8463-8470

34. Batten M, Li J, Yi S, Kljavin NM, Danilenko DM, Lucas S, Lee J, de Sauvage FJ, Ghilardi N (2006) Interleukin 27 limits autoimmune encephalomyelitis by suppressing the development of interleukin 17-producing T cells. Nat Immunol 7:929-936

35. Do J, Kim D, Kim S, Valentin-Torres A, Dvorina N, Jang E, Nagarajavel V, DeSilva TM, Li X, Ting AH, Vignali DAA, Stohlman SA, Baldwin WM 3rd, Min B (2017) Treg-specific IL-27Ralpha deletion uncovers a key role for IL-27 in Treg function to control autoimmunity. Proc Natl Acad Sci U S A 114: 10190-10195

36. Sweeney CM, Lonergan R, Basdeo SA, Kinsella K, Dungan LS, Higgins SC, Kelly PJ, Costelloe L, Tubridy N, Mills KH, Fletcher JM (2011) IL-27 mediates the response to IFN-beta therapy in multiple sclerosis patients by inhibiting Th17 cells. Brain Behav Immun 25:1170-1181

37. Lalive PH, Kreutzfeldt M, Devergne O, Metz I, Bruck W, Merkler D, Pot C (2017) Increased interleukin-27 cytokine expression in the central nervous system of multiple sclerosis patients. J Neuroinflammation 14:144

38. Koh DR, Fung-Leung WP, Ho A, Gray D, Acha-Orbea H, Mak TW (1992) Less mortality but more relapses in experimental allergic encephalomyelitis in CD8-/- mice. Science 256:1210-1213

39. Noble A, Zhao ZS, Cantor H (1998) Suppression of immune responses by CD 8 cells. II. Qa-1 on activated B cells stimulates CD8 cell suppression of T helper 2 responses. J Immunol 160:566-571

40. Hu D, Ikizawa K, Lu L, Sanchirico ME, Shinohara ML, Cantor H (2004) Analysis of regulatory CD8 T cells in Qa-1-deficient mice. Nat Immunol 5:516-523

41. Saligrama N, Zhao F, Sikora MJ, Serratelli WS, Fernandes RA, Louis DM, Yao W, Ji X, Idoyaga J, Mahajan VB, Steinmetz LM, Chien YH, Hauser SL, Oksenberg JR, Garcia KC, Davis MM (2019) Opposing $\mathrm{T}$ cell responses in experimental autoimmune encephalomyelitis. Nature 572:481-487

42. Correale J, Villa A (2008) Isolation and characterization of CD8+ regulatory T cells in multiple sclerosis. J Neuroimmunol 195:121134

43. Crawford MP, Yan SX, Ortega SB, Mehta RS, Hewitt RE, Price DA, Stastny P, Douek DC, Koup RA, Racke MK, Karandikar NJ (2004) High prevalence of autoreactive, neuroantigen-specific CD8+ T cells in multiple sclerosis revealed by novel flow cytometric assay. Blood 103:4222-4231

44. Baughman EJ, Mendoza JP, Ortega SB, Ayers CL, Greenberg BM, Frohman EM, Karandikar NJ (2011) Neuroantigen-specific $\mathrm{CD} 8+$ regulatory T-cell function is deficient during acute exacerbation of multiple sclerosis. J Autoimmun 36:115-124

45. Seidkhani-Nahal A, Noori-Zadeh A, Bakhtiyari S, Khosravi A (2019) Frequency of CD8(+) regulatory T cells in the multiple sclerosis patients: a systematic review and meta-analysis. Acta Neurol Belg 119:61-68

46. Wolf SD, Dittel BN, Hardardottir F, Janeway CA Jr (1996) Experimental autoimmune encephalomyelitis induction in genetically B cell-deficient mice. J Exp Med 184:2271-2278

47. Matsushita T, Yanaba K, Bouaziz JD, Fujimoto M, Tedder TF (2008) Regulatory B cells inhibit EAE initiation in mice while other B cells promote disease progression. J Clin Invest 118: $3420-3430$

48. Ray A, Mann MK, Basu S, Dittel BN (2011) A case for regulatory $B$ cells in controlling the severity of autoimmune-mediated inflammation in experimental autoimmune encephalomyelitis and multiple sclerosis. J Neuroimmunol 230:1-9

49. Fillatreau S, Sweenie CH, McGeachy MJ, Gray D, Anderton SM (2002) B cells regulate autoimmunity by provision of IL-10. Nat Immunol 3:944-950

50. Mann MK, Maresz K, Shriver LP, Tan Y, Dittel BN (2007) B cell regulation of CD4+CD25+ T regulatory cells and IL-10 via B7 is essential for recovery from experimental autoimmune encephalomyelitis. J Immunol 178:3447-3456

51. Khan AR, Hams E, Floudas A, Sparwasser T, Weaver CT, Fallon PG (2015) PD-L1hi B cells are critical regulators of humoral immunity. Nat Commun 6:5997

52. Shen P, Roch T, Lampropoulou V, O'Connor RA, Stervbo U, Hilgenberg E, Ries S, Dang VD, Jaimes Y, Daridon C, Li R, Jouneau L, Boudinot P, Wilantri S, Sakwa I, Miyazaki Y, Leech MD, McPherson RC, Wirtz S, Neurath M, Hoehlig K, Meinl E, Grutzkau A, Grun JR, Horn K, Kuhl AA, Dorner T, Bar-Or A, Kaufmann SHE, Anderton SM, Fillatreau S (2014) IL-35producing $\mathrm{B}$ cells are critical regulators of immunity during autoimmune and infectious diseases. Nature 507:366-370 
53. Bjarnadottir K, Benkhoucha M, Merkler D, Weber MS, Payne NL, Bernard CCA, Molnarfi N, Lalive PH (2016) B cell-derived transforming growth factor-betal expression limits the induction phase of autoimmune neuroinflammation. Sci Rep 6:34594

54. Knippenberg S, Peelen E, Smolders J, Thewissen M, Menheere P, Cohen Tervaert JW, Hupperts R, Damoiseaux J (2011) Reduction in IL-10 producing B cells (Breg) in multiple sclerosis is accompanied by a reduced naive/memory Breg ratio during a relapse but not in remission. J Neuroimmunol 239:80-86

55. Michel L, Chesneau M, Manceau P, Genty A, Garcia A, Salou M, Elong Ngono A, Pallier A, Jacq-Foucher M, Lefrère F, Wiertlewski S, Soulillou J-P, Degauque N, Laplaud D-A, Brouard S (2014) Unaltered regulatory B-cell frequency and function in patients with multiple sclerosis. Clin Immunol 155:198208

56. de Andres C, Tejera-Alhambra M, Alonso B, Valor L, Teijeiro R, Ramos-Medina R, Mateos D, Faure F, Sanchez-Ramon S (2014) New regulatory CD19(+)CD25(+) B-cell subset in clinically isolated syndrome and multiple sclerosis relapse. Changes after glucocorticoids. J Neuroimmunol 270:37-44

57. Machado-Santos J, Saji E, Troscher AR, Paunovic M, Liblau R, Gabriely G, Bien CG, Bauer J, Lassmann H (2018) The compartmentalized inflammatory response in the multiple sclerosis brain is composed of tissue-resident CD8+ T lymphocytes and B cells. Brain 141:2066-2082

58. Rojas OL, Probstel AK, Porfilio EA, Wang AA, Charabati M, Sun T, Lee DSW, Galicia G, Ramaglia V, Ward LA, Leung LYT, Najafi G, Khaleghi K, Garcillan B, Li A, Besla R, Naouar I, Cao EY, Chiaranunt P, Burrows K, Robinson HG, Allanach JR, Yam J, Luck H, Campbell DJ, Allman D, Brooks DG, Tomura M, Baumann R, Zamvil SS, Bar-Or A, Horwitz MS, Winer DA, Mortha A, Mackay F, Prat A, Osborne LC, Robbins C, Baranzini SE, Gommerman JL (2019) Recirculating intestinal IgA-producing cells regulate neuroinflammation via IL-10. Cell 176:610-24 e18

59. Caligiuri MA (2008) Human natural killer cells. Blood 112:461469

60. Laroni A, Gandhi R, Beynon V, Weiner HL (2011) IL-27 imparts immunoregulatory function to human NK cell subsets. PLoS One 6:e26173

61. Gross CC, Schulte-Mecklenbeck A, Wiendl H, Marcenaro E, Kerlero de Rosbo N, Uccelli A, Laroni A (2016) Regulatory functions of natural killer cells in multiple sclerosis. Front Immunol 7: 606

62. Laroni A (2019) Enhancing natural killer cells is beneficial in multiple sclerosis - Yes. Mult Scler 25:510-512

63. Gross CC, Schulte-Mecklenbeck A, Runzi A, Kuhlmann T, Posevitz-Fejfar A, Schwab N, Schneider-Hohendorf T, Herich S, Held K, Konjevic M, Hartwig M, Dornmair K, Hohlfeld R, Ziemssen T, Klotz L, Meuth SG, Wiendl H (2016) Impaired NK-mediated regulation of T-cell activity in multiple sclerosis is reconstituted by IL-2 receptor modulation. Proc Natl Acad Sci U S A 113:E2973-E2982

64. Rauer S, Stork L, Urbach H, Stathi A, Marx A, Suss P, Prinz M, Bruck W, Metz I (2018) Drug reaction with eosinophilia and systemic symptoms after daclizumab therapy. Neurology 91:e359ee63

65. Raine CS (2017) Multiple sclerosis: the resolving lesion revealed. J Neuroimmunol 304:2-6

66. Boven LA, Van Meurs M, Van Zwam M, Wierenga-Wolf A, Hintzen RQ, Boot RG, Aerts JM, Amor S, Nieuwenhuis EE, Laman JD (2006) Myelin-laden macrophages are anti-inflammatory, consistent with foam cells in multiple sclerosis. Brain 129: $517-526$

67. Komohara Y, Hirahara J, Horikawa T, Kawamura K, Kiyota E, Sakashita N, Araki N, Takeya M (2006) AM-3K, an anti- macrophage antibody, recognizes CD163, a molecule associated with an anti-inflammatory macrophage phenotype. J Histochem Cytochem 54:763-771

68. Zhang Z, Zhang ZY, Schittenhelm J, Wu Y, Meyermann R, Schluesener HJ (2011) Parenchymal accumulation of CD163+ macrophages/microglia in multiple sclerosis brains. J Neuroimmunol 237:73-79

69. Wang Z, Brandt S, Medeiros A, Wang S, Wu H, Dent A, Serezani CH (2015) MicroRNA 21 is a homeostatic regulator of macrophage polarization and prevents prostaglandin E2-mediated M2 generation. PLoS One 10:e 0115855

70. Schraufstatter IU, Zhao M, Khaldoyanidi SK, Discipio RG (2012) The chemokine CCL18 causes maturation of cultured monocytes to macrophages in the M2 spectrum. Immunology 135:287-298

71. Bogie JF, Jorissen W, Mailleux J, Nijland PG, Zelcer N, Vanmierlo T, Van Horssen J, Stinissen P, Hellings N, Hendriks JJ (2013) Myelin alters the inflammatory phenotype of macrophages by activating PPARs. Acta Neuropathol Commun 1:43

72. Bogie JF, Timmermans S, Huynh-Thu VA, Irrthum A, Smeets HJ, Gustafsson JA, Steffensen KR, Mulder M, Stinissen P, Hellings N, Hendriks JJ (2012) Myelin-derived lipids modulate macrophage activity by liver X receptor activation. PLoS One 7:e44998

73. Kidani Y, Bensinger SJ (2012) Liver X receptor and peroxisome proliferator-activated receptor as integrators of lipid homeostasis and immunity. Immunol Rev 249:72-83

74. Vigne S, Chalmin F, Duc D, Clottu AS, Apetoh L, Lobaccaro JA, Christen I, Zhang J, Pot C (2017) IL-27-induced type 1 regulatory T-cells produce oxysterols that constrain IL-10 production. Front Immunol 8:1184

75. Kuhlmann T, Ludwin S, Prat A, Antel J, Bruck W, Lassmann H (2017) An updated histological classification system for multiple sclerosis lesions. Acta Neuropathol 133:13-24

76. Lappat EJ, Cawein M (1964) A study of the leukemoid response to transplantable a-280 tumor in mice. Cancer Res 24:302-311

77. Crook KR, Liu P (2014) Role of myeloid-derived suppressor cells in autoimmune disease. World J Immunol 4:26-33

78. Cassetta L, Baekkevold ES, Brandau S, Bujko A, Cassatella MA, Dorhoi A, Krieg C, Lin A, Lore K, Marini O, Pollard JW, Roussel M, Scapini P, Umansky V, Adema GJ (2019) Deciphering myeloid-derived suppressor cells: isolation and markers in humans, mice and non-human primates. Cancer Immunol Immunother 68:687-697

79. Moline-Velazquez V, Cuervo H, Vila-Del Sol V, Ortega MC, Clemente D, de Castro F (2011) Myeloid-derived suppressor cells limit the inflammation by promoting $\mathrm{T}$ lymphocyte apoptosis in the spinal cord of a murine model of multiple sclerosis. Brain Pathol 21:678-691

80. Slaney CY, Toker A, La Flamme A, Backstrom BT, Harper JL (2011) Naive blood monocytes suppress T-cell function. A possible mechanism for protection from autoimmunity. Immunol Cell Biol 89:7-13

81. Ioannou M, Alissafi T, Lazaridis I, Deraos G, Matsoukas J, Gravanis A, Mastorodemos V, Plaitakis A, Sharpe A, Boumpas D, Verginis P (2012) Crucial role of granulocytic myeloid-derived suppressor cells in the regulation of central nervous system autoimmune disease. J Immunol 188:1136-1146

82. Hertzenberg D, Lehmann-Horn K, Kinzel S, Husterer V, Cravens PD, Kieseier BC, Hemmer B, Bruck W, Zamvil SS, Stuve O, Weber MS (2013) Developmental maturation of innate immune cell function correlates with susceptibility to central nervous system autoimmunity. Eur J Immunol 43:2078-2088

83. Melero-Jerez C, Suardiaz M, Lebron-Galan R, Marin-Banasco C, Oliver-Martos B, Machin-Diaz I, Fernandez O, de Castro F, Clemente D (2019) The presence and suppressive activity of myeloid-derived suppressor cells are potentiated after interferon- 
beta treatment in a murine model of multiple sclerosis. Neurobiol Dis 127:13-31

84. Knier B, Hiltensperger M, Sie C, Aly L, Lepennetier G, Engleitner T, Garg G, Muschaweckh A, Mitsdorffer M, Koedel U, Hochst B, Knolle P, Gunzer M, Hemmer B, Rad R, Merkler D, Korn T (2018) Myeloid-derived suppressor cells control B cell accumulation in the central nervous system during autoimmunity. Nat Immunol 19:1341-1351

85. Cepok S, Rosche B, Grummel V, Vogel F, Zhou D, Sayn J, Sommer N, Hartung HP, Hemmer B (2005) Short-lived plasma blasts are the main $\mathrm{B}$ cell effector subset during the course of multiple sclerosis. Brain 128:1667-1676

86. Hofman FM, Hinton DR, Johnson K, Merrill JE (1989) Tumor necrosis factor identified in multiple sclerosis brain. J Exp Med 170:607-612

87. Pegoretti V, Baron W, Laman JD, Eisel ULM (2018) Selective modulation of TNF-TNFRs signaling: insights for multiple sclerosis treatment. Front Immunol 9:925

88. Probert L (2015) TNF and its receptors in the CNS: the essential, the desirable and the deleterious effects. Neuroscience 302:2-22

89. Sharief MK, Hentges R (1991) Association between tumor necrosis factor-alpha and disease progression in patients with multiple sclerosis. N Engl J Med 325:467-472

90. 1999. TNF neutralization in MS: results of a randomized, placebocontrolled multicenter study. The Lenercept Multiple Sclerosis Study Group and The University of British Columbia MS/MRI Analysis Group. Neurology 53: 457-65

91. Robinson WH, Genovese MC, Moreland LW (2001) Demyelinating and neurologic events reported in association with tumor necrosis factor alpha antagonism: by what mechanisms could tumor necrosis factor alpha antagonists improve rheumatoid arthritis but exacerbate multiple sclerosis? Arthritis Rheum 44:1977-1983

92. Sicotte NL, Voskuhl RR (2001) Onset of multiple sclerosis associated with anti-TNF therapy. Neurology 57:1885-1888

93. Chen X, Baumel M, Mannel DN, Howard OM, Oppenheim JJ (2007) Interaction of TNF with TNF receptor type 2 promotes expansion and function of mouse $\mathrm{CD} 4+\mathrm{CD} 25+\mathrm{T}$ regulatory cells. J Immunol 179:154-161

94. Veroni C, Gabriele L, Canini I, Castiello L, Coccia E, Remoli ME, Columba-Cabezas S, Arico E, Aloisi F, Agresti C (2010) Activation of TNF receptor 2 in microglia promotes induction of anti-inflammatory pathways. Mol Cell Neurosci 45:234-244

95. Madsen PM, Motti D, Karmally S, Szymkowski DE, Lambertsen KL, Bethea JR, Brambilla R (2016) Oligodendroglial TNFR2 mediates membrane TNF-dependent repair in experimental autoimmune encephalomyelitis by promoting oligodendrocyte differentiation and remyelination. J Neurosci 36:5128-5143

96. Lopez-Gomez C, Fernandez O, Garcia-Leon JA, Pinto-Medel MJ, Oliver-Martos B, Ortega-Pinazo J, Suardiaz M, Garcia-Trujillo L, Guijarro-Castro C, Benito-Leon J, Prat I, Varade J, AlvarezLafuente R, Urcelay E, Leyva L (2011) TRAIL/TRAIL receptor system and susceptibility to multiple sclerosis. PLoS One 6: e21766

97. Nitsch R, Bechmann I, Deisz RA, Haas D, Lehmann TN, Wendling U, Zipp F (2000) Human brain-cell death induced by tumour-necrosis-factor-related apoptosis-inducing ligand (TRAIL). Lancet 356:827-828

98. Hilliard B, Wilmen A, Seidel C, Liu TS, Goke R, Chen Y (2001) Roles of TNF-related apoptosis-inducing ligand in experimental autoimmune encephalomyelitis. J Immunol 166:1314-1319

99. Duffney PF, Falsetta ML, Rackow AR, Thatcher TH, Phipps RP, Sime PJ (2018) Key roles for lipid mediators in the adaptive immune response. J Clin Invest 128:2724-2731

100. Hong S, Gronert K, Devchand PR, Moussignac RL, Serhan CN (2003) Novel docosatrienes and 17S-resolvins generated from docosahexaenoic acid in murine brain, human blood, and glial cells. Autacoids in anti-inflammation. J Biol Chem 278:1467714687

101. Marcheselli VL, Hong S, Lukiw WJ, Tian XH, Gronert K, Musto A, Hardy M, Gimenez JM, Chiang N, Serhan CN, Bazan NG (2003) Novel docosanoids inhibit brain ischemia-reperfusionmediated leukocyte infiltration and pro-inflammatory gene expression. J Biol Chem 278:43807-43817

102. Zhu M, Wang X, Hjorth E, Colas RA, Schroeder L, Granholm AC, Serhan CN, Schultzberg M (2016) Pro-resolving lipid mediators improve neuronal survival and increase Abeta42 phagocytosis. Mol Neurobiol 53:2733-2749

103. Pruss H, Rosche B, Sullivan AB, Brommer B, Wengert O, Gronert K, Schwab JM (2013) Proresolution lipid mediators in multiple sclerosis - differential, disease severity-dependent synthesis - a clinical pilot trial. PLoS One 8:e55859

104. Poisson LM, Suhail H, Singh J, Datta I, Denic A, Labuzek K, Hoda MN, Shankar A, Kumar A, Cerghet M, Elias S, Mohney RP, Rodriguez M, Rattan R, Mangalam AK, Giri S (2015) Untargeted plasma metabolomics identifies endogenous metabolite with drug-like properties in chronic animal model of multiple sclerosis. J Biol Chem 290:30697-30712

105. Wang X, Jiao W, Lin M, Lu C, Liu C, Wang Y, Ma D, Wang X, Yin P, Feng J, Zhu J, Zhu M (2019) Resolution of inflammation in neuromyelitis optica spectrum disorders. Mult Scler Relat Disord 27:34-41

106. Sedighian M, Djafarian K, Dabiri S, Abdollahi M, Shab-Bidar S (2019) Effect of omega-3 supplementation on expanded disability status scale and inflammatory cytokines in multiple sclerosis: a systematic review and meta-analysis of randomized controlled trials. CNS Neurol Disord Drug Targets

107. Medawar PB (1948) Immunity to homologous grafted skin; the fate of skin homografts transplanted to the brain, to subcutaneous tissue, and to the anterior chamber of the eye. Br J Exp Pathol 29: $58-69$

108. Engelhardt B, Coisne C (2011) Fluids and barriers of the CNS establish immune privilege by confining immune surveillance to a two-walled castle moat surrounding the CNS castle. Fluids Barriers CNS 8:4

109. Takeshita Y, Ransohoff RM (2012) Inflammatory cell trafficking across the blood-brain barrier: chemokine regulation and in vitro models. Immunol Rev 248:228-239

110. Muoio V, Persson PB, Sendeski MM (2014) The neurovascular unit - concept review. Acta Physiol (Oxf) 210:790-798

111. Colombo E, Farina C (2016) Astrocytes: key regulators of neuroinflammation. Trends Immunol 37:608-620

112. Senecal V, Deblois G, Beauseigle D, Schneider R, Brandenburg J, Newcombe J, Moore CS, Prat A, Antel J, Arbour N (2016) Production of IL-27 in multiple sclerosis lesions by astrocytes and myeloid cells: modulation of local immune responses. Glia 64:553-569

113. Okuda Y, Sakoda S, Bernard CC, Fujimura H, Saeki Y, Kishimoto T, Yanagihara T (1998) IL-6-deficient mice are resistant to the induction of experimental autoimmune encephalomyelitis provoked by myelin oligodendrocyte glycoprotein. Int Immunol 10: 703-708

114. Haroon F, Drogemuller K, Handel U, Brunn A, Reinhold D, Nishanth G, Mueller W, Trautwein C, Ernst M, Deckert M, Schluter D (2011) Gp130-dependent astrocytic survival is critical for the control of autoimmune central nervous system inflammation. J Immunol 186:6521-6531

115. Hulshof S, Montagne L, De Groot CJ, Van Der Valk P (2002) Cellular localization and expression patterns of interleukin-10, interleukin- 4 , and their receptors in multiple sclerosis lesions. Glia 38:24-35 
116. Perriot S, Mathias A, Perriard G, Canales M, Jonkmans N, Merienne N, Meunier C, El Kassar L, Perrier AL, Laplaud DA, Schluep M, Deglon N, Du Pasquier R (2018) Human induced pluripotent stem cell-derived astrocytes are differentially activated by multiple sclerosis-associated cytokines. Stem Cell Rep 11: 1199-1210

117. Baert L, Benkhoucha M, Popa N, Ahmed MC, Manfroi B, Boutonnat J, Sturm N, Raguenez G, Tessier M, Casez O, Marignier R, Ahmadi M, Broisat A, Ghezzi C, Rivat C, Sonrier C, Hahne M, Baeten D, Vives RR, Lortat-Jacob H, Marche PN, Schneider P, Lassmann HP, Boucraut J, Lalive PH, Huard B (2019) A proliferation-inducing ligand-mediated antiinflammatory response of astrocytes in multiple sclerosis. Ann Neurol 85:406-420

118. Alvarez JI, Dodelet-Devillers A, Kebir H, Ifergan I, Fabre PJ, Terouz S, Sabbagh M, Wosik K, Bourbonniere L, Bernard M, van Horssen J, de Vries HE, Charron F, Prat A (2011) The Hedgehog pathway promotes blood-brain barrier integrity and CNS immune quiescence. Science 334:1727-1731

119. Podjaski C, Alvarez JI, Bourbonniere L, Larouche S, Terouz S, Bin JM, Lecuyer MA, Saint-Laurent O, Larochelle C, Darlington PJ, Arbour N, Antel JP, Kennedy TE, Prat A (2015) Netrin 1 regulates blood-brain barrier function and neuroinflammation. Brain 138:1598-1612

120. Pekny M, Pekna M (2016) Reactive gliosis in the pathogenesis of CNS diseases. Biochim Biophys Acta 1862:483-491

121. Voskuhl RR, Peterson RS, Song B, Ao Y, Morales LB, TiwariWoodruff S, Sofroniew MV (2009) Reactive astrocytes form scarlike perivascular barriers to leukocytes during adaptive immune inflammation of the CNS. J Neurosci 29:11511-11522

122. Horng S, Therattil A, Moyon S, Gordon A, Kim K, Argaw AT, Hara Y, Mariani JN, Sawai S, Flodby P, Crandall ED, Borok Z, Sofroniew MV, Chapouly C, John GR (2017) Astrocytic tight junctions control inflammatory CNS lesion pathogenesis. J Clin Invest 127:3136-3151

123. Liu Y, Teige I, Birnir B, Issazadeh-Navikas S (2006) Neuronmediated generation of regulatory $\mathrm{T}$ cells from encephalitogenic T cells suppresses EAE. Nat Med 12:518-525

124. Liu Y, Carlsson R, Comabella M, Wang J, Kosicki M, Carrion B, Hasan M, Wu X, Montalban X, Dziegiel MH, Sellebjerg F, Sorensen PS, Helin K, Issazadeh-Navikas S (2014) FoxA1 directs the lineage and immunosuppressive properties of a novel regulatory T cell population in EAE and MS. Nat Med 20:272-282

125. Joller N, Peters A, Anderson AC, Kuchroo VK (2012) Immune checkpoints in central nervous system autoimmunity. Immunol Rev 248:122-139

126. Liu Y, Marin A, Ejlerskov P, Rasmussen LM, Prinz M, IssazadehNavikas S (2017) Neuronal IFN-beta-induced PI3K/Akt-FoxA1 signalling is essential for generation of FoxA1(+)Treg cells. Nat Commun 8:14709

127. Redzic Z (2011) Molecular biology of the blood-brain and the blood-cerebrospinal fluid barriers: similarities and differences. Fluids Barriers CNS 8:3

128. Wolburg H, Paulus W (2010) Choroid plexus: biology and pathology. Acta Neuropathol 119:75-88

129. Shechter R, London A, Schwartz M (2013) Orchestrated leukocyte recruitment to immune-privileged sites: absolute barriers versus educational gates. Nat Rev Immunol 13:206-218

130. Gordon LB, Nolan SC, Ksander BR, Knopf PM, Harling-Berg CJ (1998) Normal cerebrospinal fluid suppresses the in vitro development of cytotoxic T cells: role of the brain microenvironment in CNS immune regulation. J Neuroimmunol 88:77-84

131. Shechter R, Miller O, Yovel G, Rosenzweig N, London A, Ruckh J, Kim KW, Klein E, Kalchenko V, Bendel P, Lira SA, Jung S, Schwartz M (2013) Recruitment of beneficial M2 macrophages to injured spinal cord is orchestrated by remote brain choroid plexus. Immunity 38:555-569

132. Reboldi A, Coisne C, Baumjohann D, Benvenuto F, Bottinelli D, Lira S, Uccelli A, Lanzavecchia A, Engelhardt B, Sallusto F (2009) C-C chemokine receptor 6-regulated entry of TH-17 cells into the CNS through the choroid plexus is required for the initiation of EAE. Nat Immunol 10:514-523

133. Yamazaki T, Yang XO, Chung Y, Fukunaga A, Nurieva R, Pappu B, Martin-Orozco N, Kang HS, Ma L, Panopoulos AD, Craig S, Watowich SS, Jetten AM, Tian Q, Dong C (2008) CCR6 regulates the migration of inflammatory and regulatory T cells. J Immunol 181:8391-8401

134. Choi EY, Chavakis E, Czabanka MA, Langer HF, Fraemohs L, Economopoulou M, Kundu RK, Orlandi A, Zheng YY, Prieto DA, Ballantyne CM, Constant SL, Aird WC, Papayannopoulou T, Gahmberg CG, Udey MC, Vajkoczy P, Quertermous T, Dimmeler S, Weber C, Chavakis T (2008) Del-1, an endogenous leukocyte-endothelial adhesion inhibitor, limits inflammatory cell recruitment. Science 322:1101-1104

135. Goris A, Sawcer S, Vandenbroeck K, Carton H, Billiau A, Setakis E, Compston A, Dubois B (2003) New candidate loci for multiple sclerosis susceptibility revealed by a whole genome association screen in a Belgian population. J Neuroimmunol 143:65-69

136. Choi EY, Lim JH, Neuwirth A, Economopoulou M, Chatzigeorgiou A, Chung KJ, Bittner S, Lee SH, Langer H, Samus M, Kim H, Cho GS, Ziemssen T, Bdeir K, Chavakis E, Koh JY, Boon L, Hosur K, Bornstein SR, Meuth SG, Hajishengallis G, Chavakis T (2015) Developmental endothelial locus-1 is a homeostatic factor in the central nervous system limiting neuroinflammation and demyelination. Mol Psychiatry 20:880-888

137. Kourtzelis I, Li X, Mitroulis I, Grosser D, Kajikawa T, Wang B, Grzybek M, von Renesse J, Czogalla A, Troullinaki M, Ferreira A, Doreth C, Ruppova K, Chen LS, Hosur K, Lim JH, Chung KJ, Grossklaus S, Tausche AK, Joosten LAB, Moutsopoulos NM, Wielockx B, Castrillo A, Korostoff JM, Coskun U, Hajishengallis G, Chavakis T (2019) DEL-1 promotes macrophage efferocytosis and clearance of inflammation. Nat Immunol 20:40-49

138. Heidbrink C, Hausler SF, Buttmann M, Ossadnik M, Strik HM, Keller A, Buck D, Verbraak E, van Meurs M, Krockenberger M, Mehling M, Mittelbronn M, Laman JD, Wiendl H, Wischhusen J (2010) Reduced cortisol levels in cerebrospinal fluid and differential distribution of 11 beta-hydroxysteroid dehydrogenases in multiple sclerosis: implications for lesion pathogenesis. Brain Behav Immun 24:975-984

139. Tischner D, Reichardt HM (2007) Glucocorticoids in the control of neuroinflammation. Mol Cell Endocrinol 275:62-70

140. Chen X, Murakami T, Oppenheim JJ, Howard OMZ (2004) Differential response of murine CD4+CD25+ and CD4+CD25$\mathrm{T}$ cells to dexamethasone-induced cell death. Eur J Immunol 34: 859-869

141. Navarro J, Aristimuno C, Sanchez-Ramon S, Vigil D, MartinezGines ML, Fernandez-Cruz E, de Andres C (2006) Circulating dendritic cells subsets and regulatory T-cells at multiple sclerosis relapse: differential short-term changes on corticosteroids therapy. J Neuroimmunol 176:153-161

142. Massey JC, Sutton IJ, Ma DDF, Moore JJ (2018) Regenerating immunotolerance in multiple sclerosis with autologous hematopoietic stem cell transplant. Front Immunol 9:410

143. Arruda LCM, Malmegrim KCR, Lima-Junior JR, Clave E, Dias JBE, Moraes DA, Douay C, Fournier I, Moins-Teisserenc H, Alberdi AJ, Covas DT, Simoes BP, Lansiaux P, Toubert A, Oliveira MC (2018) Immune rebound associates with a favorable clinical response to autologous HSCT in systemic sclerosis patients. Blood Adv 2:126-141 
144. Salama AD, Chitnis T, Imitola J, Ansari MJ, Akiba H, Tushima F, Azuma M, Yagita H, Sayegh MH, Khoury SJ (2003) Critical role of the programmed death-1 (PD-1) pathway in regulation of experimental autoimmune encephalomyelitis. J Exp Med 198:71-78

145. Trabattoni D, Saresella M, Pacei M, Marventano I, Mendozzi L, Rovaris M, Caputo D, Borelli M, Clerici M (2009) Costimulatory pathways in multiple sclerosis: distinctive expression of PD-1 and PD-L1 in patients with different patterns of disease. J Immunol 183:4984-4993

146. De Mercanti S, Rolla S, Cucci A, Bardina V, Cocco E, Vladic A, Soldo-Butkovic S, Habek M, Adamec I, Horakova D, Annovazzi P, Novelli F, Durelli L, Clerico M (2016) Alemtuzumab long-term immunologic effect: Treg suppressor function increases up to 24 months. Neurol Neuroimmunol Neuroinflamm 3:e194

147. Baker D, Herrod SS, Alvarez-Gonzalez C, Giovannoni G, Schmierer K (2017) Interpreting lymphocyte reconstitution data from the pivotal phase 3 trials of alemtuzumab. JAMA Neurol 74: 961-969
148. Yurdagul A Jr, Doran AC, Cai B, Fredman G, Tabas IA (2017) Mechanisms and consequences of defective efferocytosis in atherosclerosis. Front Cardiovasc Med 4:86

149. Mexhitaj I, Nyirenda MH, Li R, O'Mahony J, Rezk A, Rozenberg A, Moore CS, Johnson T, Sadovnick D, Collins DL, Arnold DL, Gran B, Yeh EA, Marrie RA, Banwell B, Bar-Or A (2019) Abnormal effector and regulatory $\mathrm{T}$ cell subsets in paediatriconset multiple sclerosis. Brain 142:617-632

150. Merkler D, Ernsting T, Kerschensteiner M, Bruck W, Stadelmann C (2006) A new focal EAE model of cortical demyelination: multiple sclerosis-like lesions with rapid resolution of inflammation and extensive remyelination. Brain 129:1972-1983

Publisher's note Springer Nature remains neutral with regard to jurisdictional claims in published maps and institutional affiliations. 